\title{
Phytobiological Facilitated Production of Silver Nanoparticles from Selected Non-Cultivated Vegetables in Nigeria and Their Biological Potential.
}

Bello Oluwasesan Micheal ${ }^{1,2}$, Oguntoye Stephen O. ${ }^{1}$, Dada Oluwasogo A..${ }^{4}$, Bello Oluwatoyin Eunice ${ }^{3}$, Tijjani Ali ${ }^{2}$ Ahmad Abdullahi Alhaji ${ }^{1}$ and Adeniyi Oluwatosin Urel ${ }^{1}$

Corresponding Author: Bello Oluwasesan Micheal (PhD)

Email: obello@,fudutsinma.edu.ng

1. Department of Chemistry, University of Ilorin, Ilorin, Kwara State

2. Department of Applied Chemistry, Federal University Dutsin-Ma, Dutsin-Ma, Katsina State, Nigeria.

3. Dept. of Crop Protection, University of Ilorin, Kwara State.

4. Industrial Chemistry Programme, Department of Physical Sciences, Nanotechnology

Laboratory, Landmark University, Omu Aran, Kwara State, Nigeria 


\section{Abstract}

Plant-mediated synthesis (Silver ( $\mathrm{Ag}$ ) to form nanoparticles) is progressively becoming well accepted in many scientific and pharmaceutical fields. This study is aimed at synthesizing Ag nanoparticles using air-dried leaves of four (4) neglected vegetables i.e. Cerathoteca sesamoides, Ceiba pentandra, Crassocephalum crepidioides, Launaea taraxacifolia. Ultravioletvisible spectroscopy, Fourier transform infrared spectroscopy (FT-IR) and scanning electron microscopy (SEM) were used for characterization. Cell Stabilization Membrane (CSM) and lipoxidase assays, DPPH and ABTS+ assays were used to assess the anti-inflammatory and antioxidant activities of these AgNPs. L. taraxacifolia Ag nanoparticles (LT-AgNPs), C. sesamoides Ag nanoparticles (CS-AgNPs), C. pendandra Ag nanoparticles (CP -AgNPs) and C. crepidioides Ag nanoparticles (CC-AgNPs), were noticed through visual color change. The UVVis spectra of the synthesized nanoparticles displayed absorption bands at around $360-440$ $\mathrm{nm}$, which is a characteristic band for Ag nanoparticles. The SEM image of the AgNPs formed displayed were spherical in morphology. CC-AgNPs exhibited the most significant inhibitory activity against HRBC ( $\left.\mathrm{IC}_{50}: 32.2\right)$ while CS-AgNPs displayed the most significant inhibitory activity against lipoxygenases ( $\mathrm{IC}_{50}$ : 32.8$)$. CP-AgNPs exhibited the most significant antioxidant effect against both ABTS and DPPH (IC50: 5.5 and 6.4) when compared to ascorbic acid (IC $50: 4.7$ $\mu \mathrm{g} / \mathrm{mL})$.

Keywords: AgNPs; anti-inflammatory; antioxidant; non-cultivated vegetables; nanoparticles; 


\section{Introduction}

From time memorial, cultures around the world have continuously employed and taken the advantages of edible but non-cultivated plants to give sufficient nutrition, food security wealth creation (Antia et al., 2006; Dhellot et al., 2006a; Omoti and Okyi, 1987). These noncultivated plants supply necessary and essential component of human diet supplying the body with various body minerals, protein and certain precursors of human hormones beside helping in the build-up of energy (Edmonds and Chweya, 1997; Fleuret, 1979; Onyenuga and Fetuga, 1995).

Some of the plants studied here are non-cultivated plants but eaten by the locals due to it being tagged as "poor man" vegetable. Ceratotheca sesamoides (Burkill, 1985) belongs to the Family Pedaliaceae, it is mostly found in Africa and it grows as a wild and non-cultivated plant. Though in some parts of Africa, it is being cultivated, because its similarities with the common sesame (Sesamum indicum), some call it false sesame (Van Wyk and Gericke, 2000; Vanderjagt et al., 2000). Literatures available on the plant and its consumption though widely taken as a delicacy in most West African Countries, are scanty and not sufficient (Grubben and Denton, 2004). C. sesamoides is traditionally employed in the management of diarrhea in Nigeria. The plant is used as an aphrodisiac, and in the treatment of jaundice, snake bites and skin ailments. $C$. sesamoides leaf infusions are used to facilitate delivery in both humans and animals (Bedigian, 2003, Bedigian and Adetula, 2004, Grubben and Denton, 2004, Bello et al., 2017). In northern Nigeria, $C$. sesamoides seeds are used to relieve circumcision pains.

Ceiba pentandra (Burkill, H.M. 1985) belongs to the family Malvaceae, it is native to the Caribbean, Central America, Northern South America, Mexico and to tropical West Africa. Beside, its young leaves nutritional benefits, in Nigeria, many locals use its leaves for treating many ailments. This plant has many ethnobotanical uses (Table 1) i.e. treatment against headache, diuretic, aphrodisiac, diabetes. Its use as one of the main ingredients in a hallucinogenic drink has been acclaimed (Adebisi, 2000; Bello et al., 2018c).

Crassocephalum crepidioides (Burkill, 1985) is also called thickhead, fireweed, Okinawa spinach, and red flower ragleaf in English, Ebolo or Ebire (Yoruba) in Nigeria. Its use is widespread in 
many tropical and subtropical regions, but is especially prominent in tropical Africa. It has also been widely cultivated in Asia due to its medicinal and nutritional properties (Burkill, 1995; Robert, 1955). In Southern Nigeria, C. crepidioides' leaves have been reported to be valuable in the management of indigestion, stomach ache, fresh wound (in Uganda), its leaves' decoction is employed in Nigeria against headache (Table 1). In Tanzania, a mixture of the leaf sap of $C$. crepidioides and Cymbopogon giganteus is taken by mouth against epilepsy. Its dried leaves application to stop nose bleeding and aid in sleeping (Arawande et al., 2013).

Launaea taraxacifolia (synonymous to Lactuca taraxacifolia) (Burkill, 1985) is a greenish leafy vegetable that is mainly eaten in the Western part of Nigeria. Most countries in Africa eat this vegetable either cooked or as salad i.e. Dahomey, Ghana, Senegal, Sierra-Lone (Arawande et al., 2013). Most people in West Africa call L. taraxacifolia by the name African lettuce or wild lettuce (Lydia, 2012). There are many ethno-medicinal applications of L. taraxacifolia. This leafy vegetable has been employed in managing many ailments for centuries, ailments such as diabetes, eye diseases (conjunctivitis), measles, skin diseases and yaws (Table 1). Some cultures in Nigeria rubbed its leaves concoction on the limbs of toddlers to facilitate walking (Adebisi, 1966; Bello et al., 2018b).

Many studies have reported the green synthesis of leafy vegetables extracts employing various metals i.e. the green synthesis of copper nanoparticles using Ocimum sanctum (Sathiraju et al., 2014), green synthesis of palladium nanoparticles employing Origanum vulgare leaf extract (Mohammed et al., 2017), lemon fruits were used, turmeric powder was used to steadied the green synthesis employing manganese nanoparticles (MnNPs) (Jayandran et al., 2015), the synthesis of silver nanoparticles from Curcuma longa (Ramar, 2015) and Calotropis. Beside their nutritional benefits, leafy and non-cultivated vegetables (Fig. 4) have been known to possess therapeutic uses (Bello et al., 2017; Bello et al., 2017; Oguntoye et al., 2018). However, many of these cheap but diseases preventing plant species are yet to be sufficiently studied and exploited. Hence, this study aims at: investigate the phytochemical screening of these noncultivated vegetables' leaves extract; experimentally carry out characterization and application of these medicinal plants species silver nanoparticles (AgNPs) as anti-inflammatory, antioxidant agents and acetylcholinesterase inhibitors. 


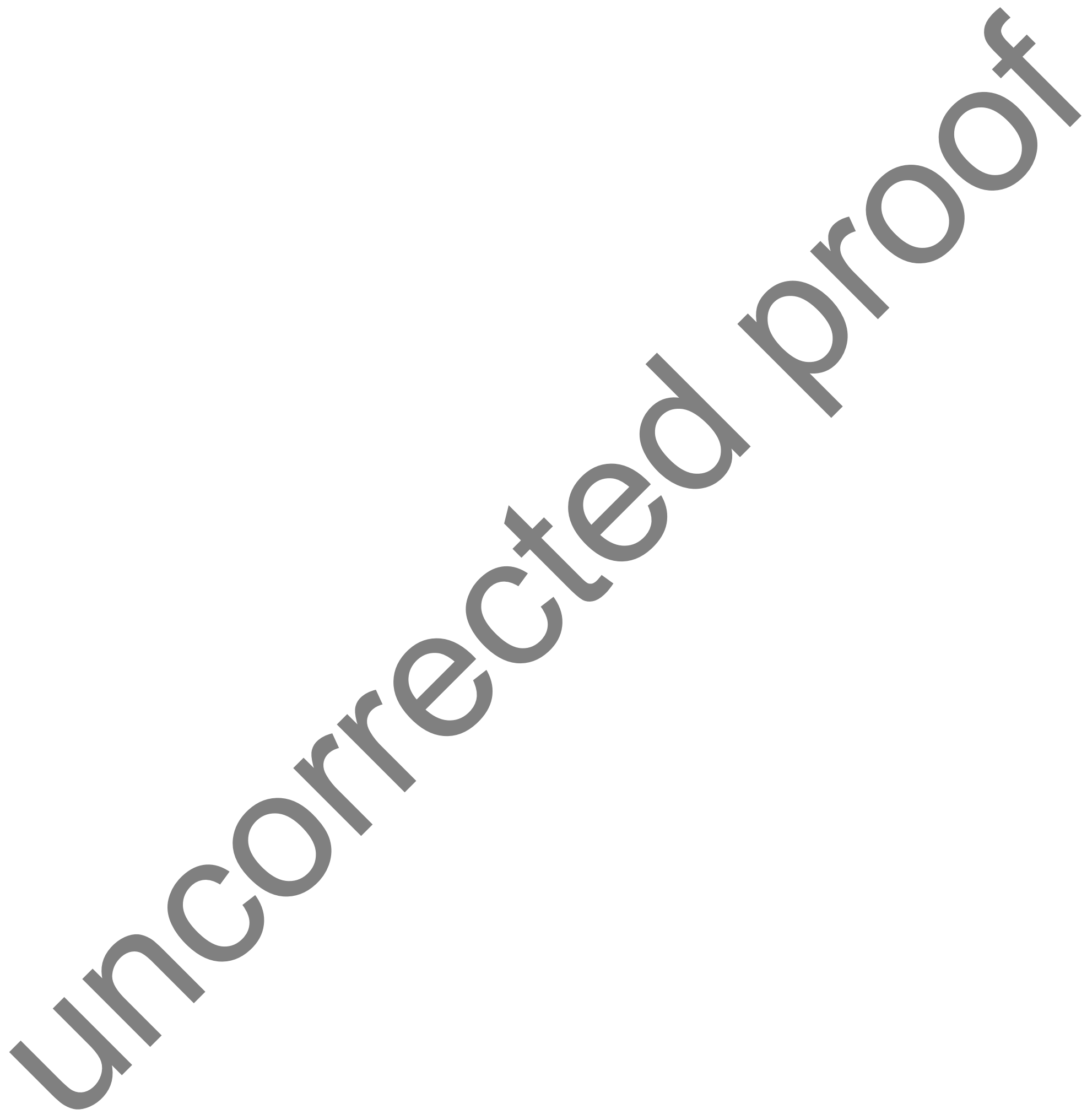




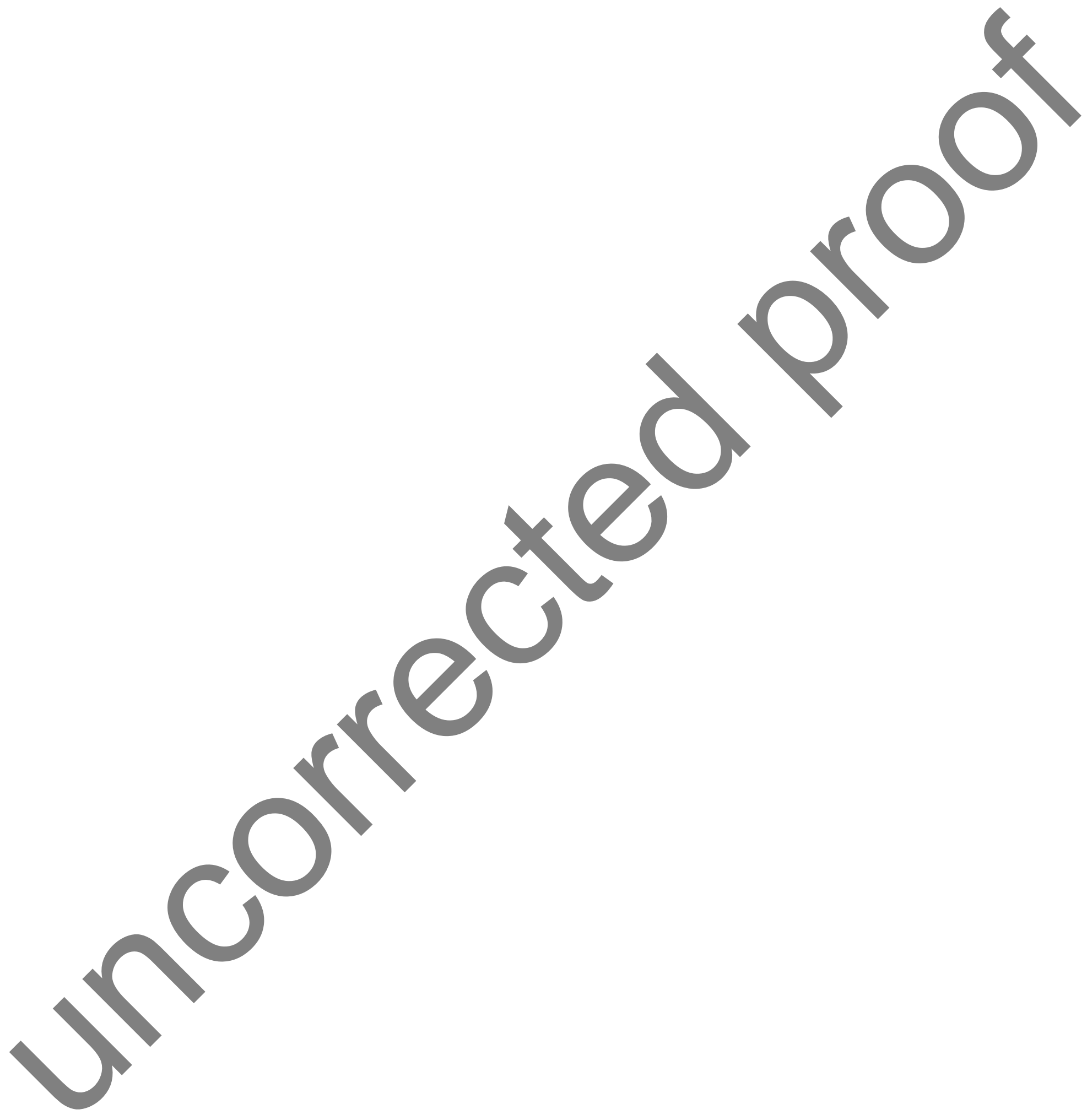


Table 1: Ethnomedicinal Importance of the Non-Cultivated Vegetables

\begin{tabular}{|c|c|c|c|c|c|c|c|}
\hline$S / N$ & $\begin{array}{l}\text { Plant } \\
\text { Name }\end{array}$ & Other Names & Country found & Ethnomedicine & & $\begin{array}{l}\text { Phytochemi } \\
\text { cal Present }\end{array}$ & References \\
\hline 1 & $\begin{array}{l}\text { C. } \\
\text { crepidioides }\end{array}$ & $\begin{array}{l}\text { Thickhead, fireweed, } \\
\text { red flower ragleaf } \\
\text { (English); Okinawa } \\
\text { spinach (Igbo); Efo } \\
\text { Ebolo or Ebire } \\
\text { (Yoruba), Ssekkoteka } \\
\text { Ekyakiragala } \\
\text { (Southern Uganda) }\end{array}$ & $\begin{array}{l}\text { Uganda, West } \\
\text { Africa countries, } \\
\text { Bangladesh, India } \\
\text { and Malaya }\end{array}$ & $\begin{array}{l}\text { Epilepsy, indigestion, } \\
\text { sickness, sleeping } \\
\text { disorder, stomach-ache, } \\
\text { swollen lips, tumor, } \\
\text { diabetes, dizziness, fever, } \\
\text { headache, hypertension, } \\
\text { leprosy, mental diseases, } \\
\text { peptic ulcer, crop yjeld } \\
\text { improvement }\end{array}$ & $\begin{array}{l}\beta \text {-Cell } \\
\text { protection, } \\
\text { antidiabetic, } \\
\text { antioxidant, } \\
\text { anticholinester } \\
\text { ases }\end{array}$ & $\begin{array}{l}\text { polyphenolic, } \\
\text { Pyrrolizidine } \\
\text { Alkaloid, } \\
\text { tannin, } \\
\text { dihydroisocou } \\
\text { marins, } \\
\text { monoterpenes } \\
\text {, }\end{array}$ & $\begin{array}{l}\text { Asada et al., 1985; } \\
\text { Rozhon et al., 2018; } \\
\text { Aniya et al., 2005; } \\
\text { Musa et al., 2011; } \\
\text { Tomimori et al., } \\
\text { 2012; Adedayo et al., } \\
\text { 2015; Ssegawa and } \\
\text { Kasenene, } 2007\end{array}$ \\
\hline 2 & $\begin{array}{l}\text { C. } \\
\text { sesamoides }\end{array}$ & $\begin{array}{l}\text { Eku (Yoruba-Western } \\
\text { Nigeria); Bungu } \\
\text { (Nigeria); Tchaba-laba } \\
\text { (Guinea Bissau); Lalu- } \\
\text { caminho (Senegal). }\end{array}$ & $\begin{array}{l}\text { Senegal, Guinea } \\
\text { Bissau, Angola, } \\
\text { Namibia, } \\
\text { Tanzania, } \\
\text { Democratic } \\
\text { Republic of } \\
\text { Congo, Nigeria, } \\
\text { Botswana, } \\
\text { Mozambique, } \\
\text { Zimbabwe and } \\
\text { Zambia }\end{array}$ & $\begin{array}{l}\text { Diarrhea, conjunctivitis, } \\
\text { emollient and lubricant, } \\
\text { stomach ache, leprosy, } \\
\text { tumour, relieve } \\
\text { circumcision pains, } \\
\text { malaria, aphrodisiac, } \\
\text { jaundice, snake bites and } \\
\text { skin ailments }\end{array}$ & $\begin{array}{l}\text { Antiviral, } \\
\text { Antidiarrhoeal, } \\
\text { Antiplasmodial, } \\
\text { Antiplasmodial, } \\
\text { Antioxidant, } \\
\text { Hyaluronidase, } \\
\text { Phospholipase } \\
\text { A2, Proteolytic }\end{array}$ & $\begin{array}{l}\text { Flavonoids } \\
\text { Saponins } \\
\text { Alkaloids } \\
\text { Tannins } \\
\text { Phenols } \\
\text { Phenolics }\end{array}$ & $\begin{array}{l}\text { Obi et al., 2006; } \\
\text { Toyin et al., 2012; } \\
\text { Benoit-Vical et al., } \\
\text { 2008; Konan et } \\
\text { al.,2014; olander et } \\
\text { al., 2014; } \\
\text { Nadembega et al., } \\
2011 \text {; Diarra et al., } \\
\text { 2015; Abubakar et } \\
\text { al., 2007; Fasola and } \\
\text { Ogunsola, } 2014\end{array}$ \\
\hline 3 & $\begin{array}{l}\text { L. } \\
\text { taraxacifolia }\end{array}$ & $\begin{array}{l}\text { Yarin/Yamurin/Odund } \\
\text { un-Odo (Yoruba); } \\
\text { Nononbarya, namijin } \\
\text { dayii (Hausa); Ugu } \\
\text { (Igbo); Yantotoé/ } \\
\text { yantoto (Fon); } \\
\text { Lantoto/ yantotoé } \\
\text { (Mahi); Odôdô/ } \\
\text { Odôdôlodôdô } \\
\text { (Idaacha) }\end{array}$ & $\begin{array}{l}\text { Nigeria, Benin, } \\
\text { Togo, Ghana, } \\
\text { Cameroon }\end{array}$ & $\begin{array}{l}\text { Malaria, Ulcer, against } \\
\text { high blood pressure, } \\
\text { diabetes mellitus, pain in } \\
\text { fresh wounds, dysentery, } \\
\text { eye diseases } \\
\text { (conjunctivitis), measles, } \\
\text { skin diseases and yaws }\end{array}$ & $\begin{array}{l}\text { Antioxidant, } \\
\text { Hypolipidemic/ } \\
\text { Antidiabetics, } \\
\text { Antibacterial, } \\
\text { Antimalarial, } \\
\text { Antiviral, } \\
\text { Anticancer }\end{array}$ & $\begin{array}{l}\text { Flavonoids,ph } \\
\text { enols, } \\
\text { Chlorogenic } \\
\text { acid }\end{array}$ & $\begin{array}{l}\text { Amujoyegbe et al., } \\
\text { 2015; Owoeye et al., } \\
\text { 2017; Obi et al., } \\
\text { 2006; Thomford et } \\
\text { al., 2016; Adetutu et } \\
\text { al., 2016; Bello et al., } \\
\text { 2017; } \\
\text { Bello et al., 2018b; } \\
\text { Adinortey et al., } \\
\text { 2012; Dairo et al., } \\
\text { 2015; Gbadamosi et } \\
\text { al., 2012; Olugbenga }\end{array}$ \\
\hline
\end{tabular}



Java cotton, Hara Nepal, Baha , Silk cotton and

Samauma is also Mexico, South known as Rimi America. West

(Hausa), Bamtami Africa Countries, (Fulani), Araba Cape Verde, Chad ogungun (Yoruba) and Akpi (Igbo) diuretic, aphrodisiac, antibacterial, headache, diabetes, to anti-

banish evil spirits. inflammatory,

hallucinogenic

bowel drink, anti-allergic,

drink, anti-allergic
complaints, antiviral,

diarrhea, hypertension, antioxidant,

headache,

constipation,

diseases, fever,

dizziness, antimicrobial,

mental anti-diarrhoeal, 2010; Adeniyi et al., 2012; Aloke et al., 2010; Anosike et al., 2014; Bello et al., 2018c; Cowan, 1999; Anigo et al., 2012; Enechi et al., 2013 


\section{Material and Methods}

Fresh green plants of Crassocephalum crepidioides (I.U. 0345), Ceratotheca sesamoide (I.U. 011), Ceiba pentandra (UILH/001/957) and Launaea taraxacifolia (UILH/002/1020) were obtained in December, 2016 from 'Oja- Oba' market in Ilorin, in Kwara State of Nigeria located in the rain forest zone on latitude $10^{\circ} 00^{\prime}$ North of the Equator and longitude $8000^{\prime}$ East of the Greenwich Meridian. The plants were identified and authenticated at Plant Biology Department, University of llorin and voucher numbers collected. The authenticated plant materials were air-dried at ambient temperature for two weeks to completely remove the moisture content and to effectively prepare the plants for the next stage of preparation. After drying, the dried leaves were crushed into fine powder using a ceramic pestle and mortar and the samples were kept in an air tight plastic container.

\section{Equipment and Reagents}

Pestle and mortal, extraction jar, rotary evaporator, centrifuging machine, ultraviolet-visible spectrophotometer and Fourier transform infrared spectrophotometer. The reagents include; n-hexane, methanol, silver nitrate, ferric chloride, potassium ferricyanide, chloroform, sulphuric acid, lead acetate, acetic anhydride, potassium hydroxide and Fehling solution. They were purchased from LABTRADE and SUNAF NIG. LTD. All solvents used were of analytical grade.

\section{Preparation of Extracts}

Powdered C. sesamoides, C. pentandra, L. taraxacifolia and C. crepidioides were macerated in 3 $\mathrm{L}$ of $\mathrm{n}$-hexane in extraction jar such that the level of the solvent was above that of the plant materials. The macerated mixtures were then left for $72 \mathrm{hrs}$ at ambient temperature. The extracts were filtered out from the macerated mixture using Whatman $185 \mu \mathrm{m}$ filter paper. The n-Hexane extracts were concentrated in a vacuum Rotary Evaporator under reduced pressure and suitable temperature, transferred to appropriately labelled $250 \mathrm{~mL}$ beaker and allowed to stand at ambient temperature to permit evaporation of residual solvents. The procedure was repeated using methanol after the residue of the $n$-hexane extract has been air-dried.

\section{Phytochemical Screening}


Preparation for the test was done by pouring $3 \mathrm{~mL}$ of the leaf extracts into separate test tubes and diluting with 2-4 mL deionized water. The various tests were carried out following the procedures described below: Standard techniques of screening and detecting secondary metabolites in plants was used (Sofowora, 1993; Trease \& Evans, 1989). The metabolites tested for were alkaloids, anthraquinones, cardiac glycosides, carbohydrates, flavonoids, saponins, steroids, phenolics, tannins and triterpenes.

\section{Synthesis of Silver Nanoparticles}

The synthesis of silver nanoparticles was carried out according to the method that has been previously described in our previous study (Dada et al., 2018). $10 \mathrm{~mL}$ of the leaf extract was measured and poured into a clean $250 \mathrm{~mL}$ beaker and reacted with $100 \mathrm{~mL}$ of $0.01 \mathrm{M} \mathrm{AgNO}_{3}$ (prepared from stock $\mathrm{AgNO}_{3}-0.1 \mathrm{M}$ of $\mathrm{AgNO}_{3}$ ) from a burette (titration method) using $\mathrm{AgNO}_{3}$ as the titrant and the extracts as the titrant at ambient temperature. A colour change to yellow was observed. The synthesized mixture was left for 24 hours and then separated by centrifugation using centrifuging machine. Clear liquid was decanted and the settled layer (nanoparticles) was stored in a $5 \mathrm{~mL}$ plastic sample viał and labelled accordingly. The following nomenclature was given to the synthesized nanoparticles: L. taraxacifolia silver nanoparticles (LT-AgNPs), C. sesamoides silver nanoparticles (CS-AgNPs), C. pendandra silver nanoparticles (CP-AgNPs) and C. crepidioides silver nanoparticles (CC-AgNPs).

\section{Characterization of Silver Nanoparticles}

The characterization of both LT-AgNPs, CS-AgNPs, CP-AgNPs and CC-AgNPs was done using a combination of analytical and spectroscopic techniques vis-à-vis UV-VIS, FTIR and SEM.

\section{- Ultraviolet- Visible Spectroscopy}

The optical properties of the AgNPs of both plants were determined by UV- visible spectroscopy on Biochrom Libra PCB 1500 UV-VIS spectrophotometer. The wavelength with the highest absorbance was determined. The absorbance of silver nanoparticle dispersed in a quartz cuvette with a $1 \mathrm{~cm}$ optical path was measured by withdrawing small aliquot from the reaction mixture and wavelength scan was taken at every 60 min interval, then 90 minutes and after 24 
hours. Varying the wavelength from $320 \mathrm{~nm}$ to $620 \mathrm{~nm}$ for L. taraxacifolia and $320 \mathrm{~nm}$ to 670 $\mathrm{nm}$ for C. crepidioides, $320 \mathrm{~nm}$ to $620 \mathrm{~nm}$ for C. sesamoides and $320 \mathrm{~nm}$ to $620 \mathrm{~nm}$ for $C$. pentandra.

\section{- Fourier Transform Infrared Spectroscopy}

The functional groups present in the methanolic extract of L. taraxacifolia, C. crepidioides, C. sesamoides and $C$. pendantra which were responsible for capping and efficient stabilization of the synthesized AgNPs were determined using SHIMADZU FTIR model IR8400s spectrophotometer. The solutions were dried at $75^{\circ} \mathrm{C}$ and the dried powders were characterized in the range $4000-400 \mathrm{~cm}^{-1}$ using $\mathrm{KBr}$ pellet method.

\section{- Scanning Electron Microscopy}

Nanoparticles of these plants' extracts were viewed using an Ultra Plus FEGSEM (Carl Zeiss, Germany) and the size and shape of the nanoparticles were determined using the Smart SEM Ver. 5 software (Carl Zeiss, Germany).

\section{Biological Activities}

\section{Anti-inflammatory Activity}

\section{- Cell Stabilization Membrane (CSM)}

The anti-inflammatory activity of these extracts was tested by in-vitro (HRBC) Human Red Blood Cell Membrane Stabilization method. The reaction mixtures $(4.5 \mathrm{~mL})$ will consist of $2 \mathrm{~mL}$ hypotonic saline solution, phosphate buffer $(\mathrm{pH} \mathrm{7.4)}$ and $1 \mathrm{~mL}$ test solution in normal saline. 0.5 $\mathrm{mL}$ of $10 \%$ rabbit RBC in normal saline was added. For control tests, $1 \mathrm{~mL}$ of isotonic solution was used. The mixtures were incubated at $560{ }^{\circ} \mathrm{C}$ for $30 \mathrm{~min}$ cooled under running water and centrifuged while the absorbance of the supernatants were read at $560 \mathrm{~nm}$. Percentage membrane stabilizing activity was calculated as follows:

$\%$ Stabilization $=(100-$ O. D. of drug sample/O. D. of control $) \times 100$

The control represents $100 \%$ lysis. The result was compared with STD $(100 \mu \mathrm{g} / \mathrm{ml})$ treated samples (Oyedapo et al., 1997; 2004). 


\section{- Lipoxidase Assay}

The inhibitory activity against lipoxygenases was studied using linoleic acid as substrate and lipoxidase as enzyme. Test samples were dissolved in $0.25 \mathrm{~mL}$ of $2 \mathrm{M}$ borate buffer $\mathrm{pH} 9.0$ and added $0.25 \mathrm{~mL}$ of lipoxidase enzyme solution $(20,000 \mathrm{U} / \mathrm{mL}$ ) and incubated for $5 \mathrm{~min}$ at $250 \mathrm{C}$. After which, $1.0 \mathrm{~mL}$ of lenoleic acid solution $(0.6 \mathrm{mM})$ was added, mixed well and absorbance was measured at $234 \mathrm{~nm}$. Indomethacin was used as reference standard. The percent inhibition was calculated from the following equation,

$\%$ inhibition $=[\{$ Abs control- Abs sample $\} /$ Abs control $] \times 100$

All tests and analyses were run in triplicate and averaged (Shinde et al., 1999; Stenhilder, 1995).

\section{Antioxidant Activity}

- 2, 2-diphenyl-1-picrylhydrazyl (DPPH) Activity.

The method employed was the one reported by Oguntoye et al., (2018) though with slight modifications (Atolani et al., 2012). Mean \pm standard error of the mean of two independent experiments run in duplicate was used to present the results.

- 2, 2'-azino-bis-(3-ethyl) benzothiazoline-6-sulfonic acid (ABTS) radical cation scavenging Activity (ABTS).

The 2,2'-azinobis-3-ethylbenzothiazoline-6- sulfonate, ABTS radical cation decolourization assay based on the scavenging of ABTS++ radicals by antioxidants component of the extracts was used. The assay follows the procedure of Oguntoye et al., (2018), with slight modifications (Atolani et al., 2012). All analysis was determined in duplicate.

\section{Result and Discussion}

\section{Phytochemical Screening}

Phytochemical constituents of the extracts of $C$. crepidioides, C. sesamoides, $C$. pendranta and L. taraxacifolia are shown in Table 2. On the whole, polyphenol, flavonoids, triterpenes and steroids were identified in all plants' extracts. Alkaloids and saponnins are absent in most of these plants except for methanol extract of $C$. crepidioides and hexane extract of $C$. pendranta. 
The hexane extracts of $C$. sesamoides gave a poor result for most groups of secondary metabolites investigated as showed in Table 2 . The phytochemical screening reveals that flavonoids are present in the various extracts. 
Table 2: Phytochemical Screening Result.

\begin{tabular}{|c|c|c|c|c|c|c|c|c|}
\hline & \multicolumn{2}{|c|}{ C. crepidioides } & \multicolumn{2}{|c|}{ C. sesamoides } & \multicolumn{2}{|c|}{ L. taraxacifolia } & \multicolumn{2}{|c|}{ C. pentandra } \\
\hline & $\mathrm{MeOH}$ & Hexane & $\mathrm{MeOH}$ & Hexane & $\mathrm{MeOH}$ & Hexane & $\mathrm{MeOH}$ & Hexane \\
\hline Polyphenol & +++ & + & +++ & - & & + & - & + \\
\hline Flavonoids & +++ & + & +++ & - & & + & ++ & + \\
\hline Triterpenes & ++ & ++ & ++ & & & +++ & +++ & + \\
\hline Saponnins & - & - & - & & - & + & - & +++ \\
\hline Alkaloids & +++ & - & ++ & & ++ & - & - & - \\
\hline Steroids & ++ & ++ & +++ & & + & - & ++ & ++ \\
\hline Phenols & ++ & ++ & +++ & ++ & +++ & ++ & +++ & ++ \\
\hline
\end{tabular}

$+++=$ Very Good, $++=$ Good, $+=$ Fair, - =Not present, $\mathrm{MeOH}=$ Methanol

Table 3: AgNPs Colour Changes observed

\begin{tabular}{llcc}
\hline & Plant Name & & Colour Change \\
\hline & & Initial & Final \\
$\mathbf{1}$ & C. crepidioides & Black & brown \\
$\mathbf{2}$ & Ceratotheca sesamoides & Blackgreenish & Yellow \\
$\mathbf{4}$ & Ceiba pentandra & deep brown & Yellow \\
\hline Table 4: Antioxidant Activity of the Synthesized AgNPs and Extracts of the Plant Species
\end{tabular}

Table 4: Antioxidant Activity of the Synthesized AgNPs and Extracts of the Plant Species

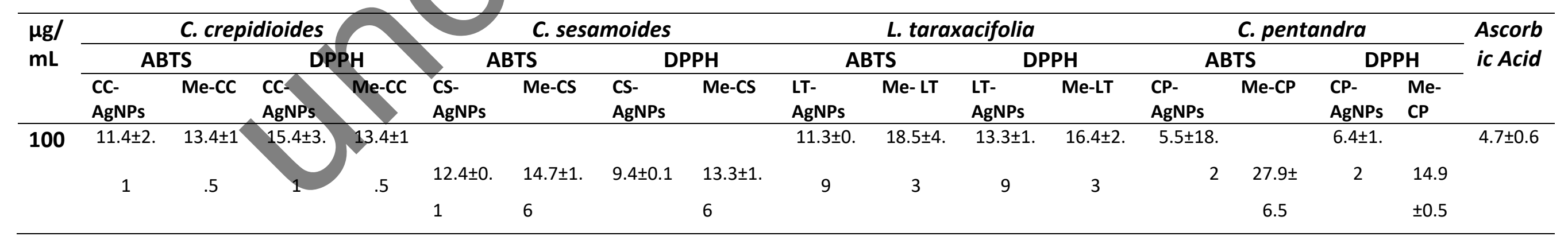


Table 5: Anti-inflammatory Activity of the Synthesized AgNPs and Extracts of the Plant Species

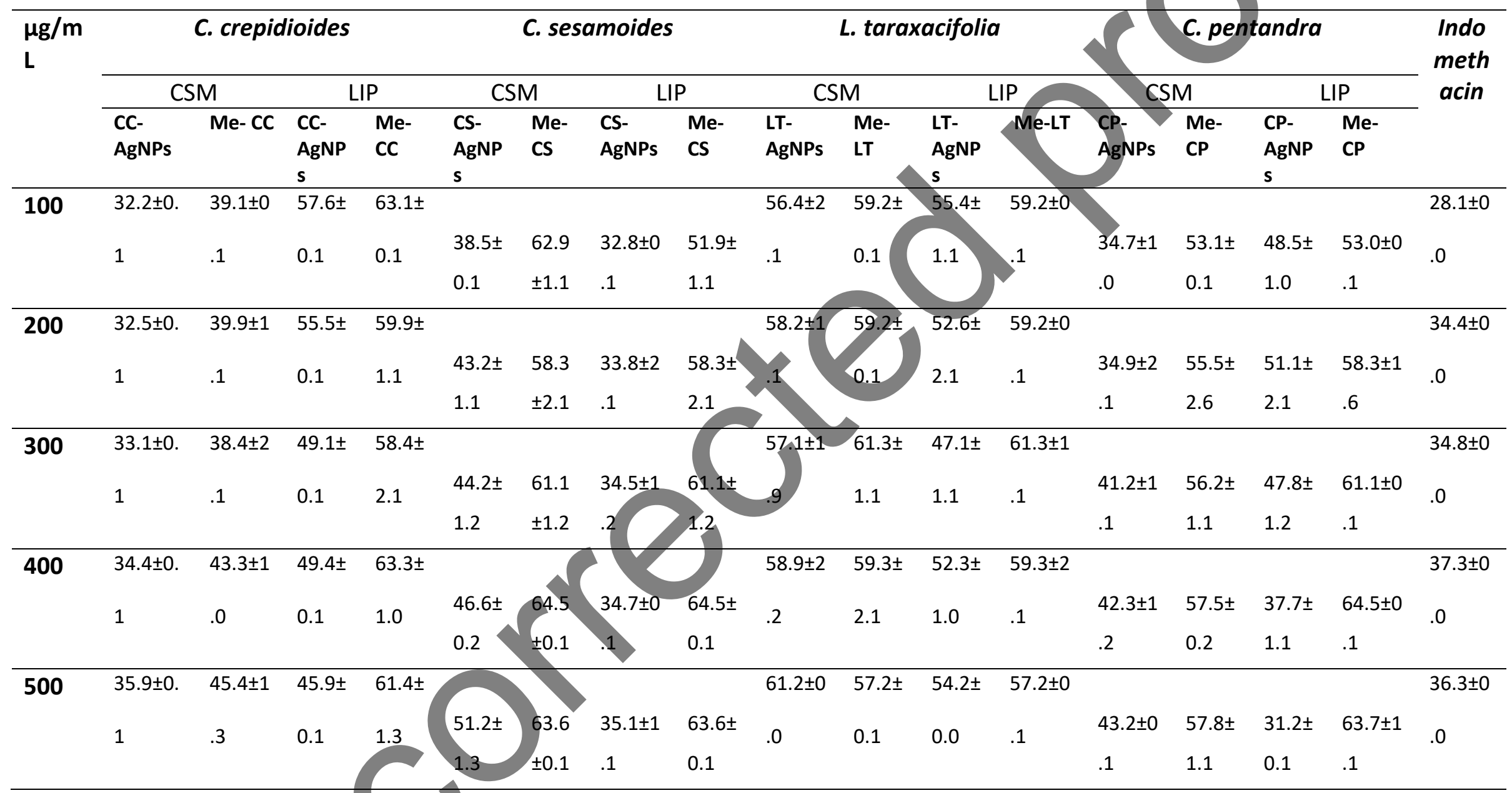

Me-CC= Methanol Extract of C. crepidioides; Me-CS=Methanol Extract of C. sesamoides; Me-LT= Methanol Extract of L. taraxacifolia; Me-CP= Methanol Extract of $C$. pentandra: The $I C_{50}$ are means of three replicates $(N=3 \pm S D)$. 


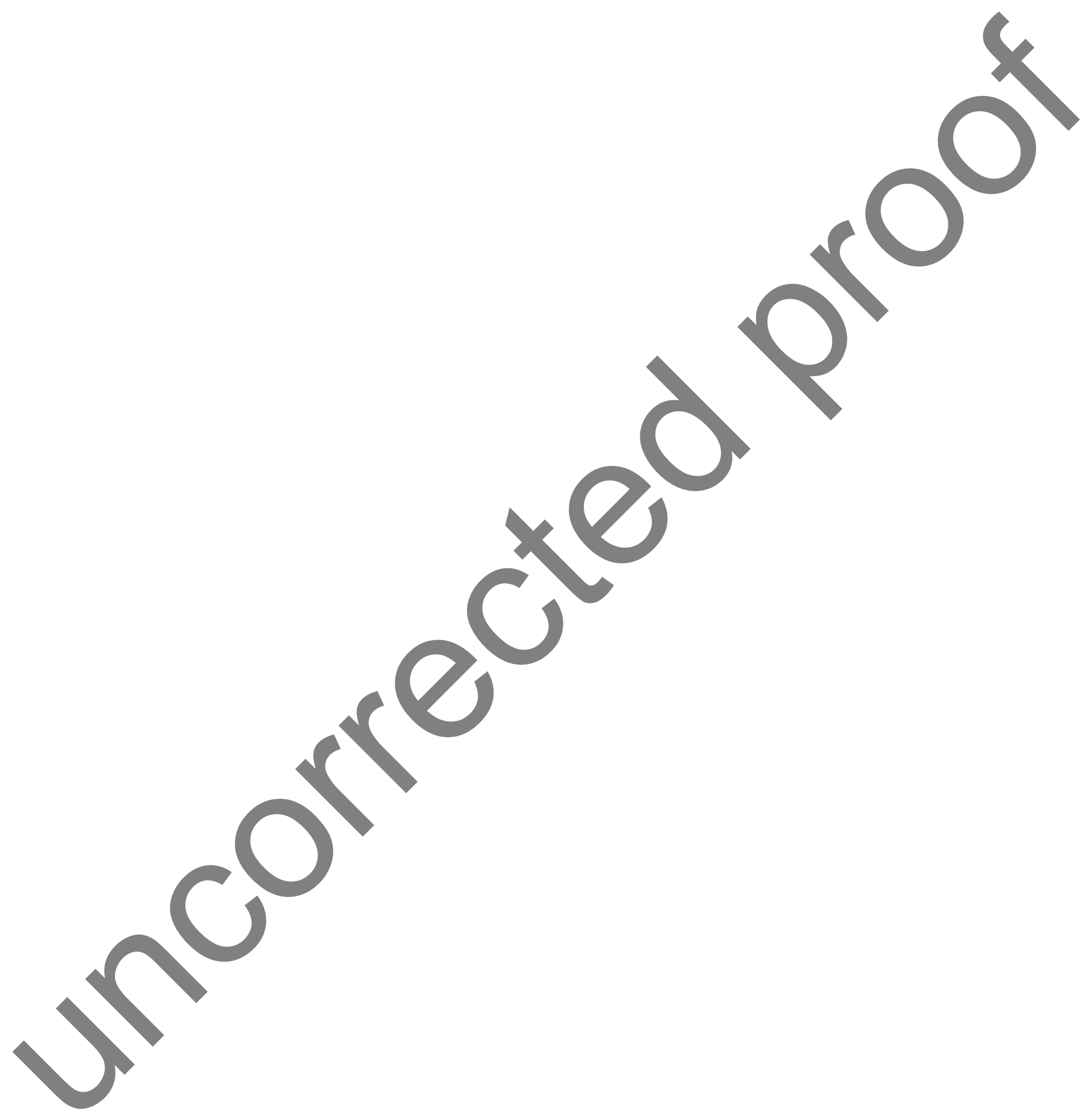




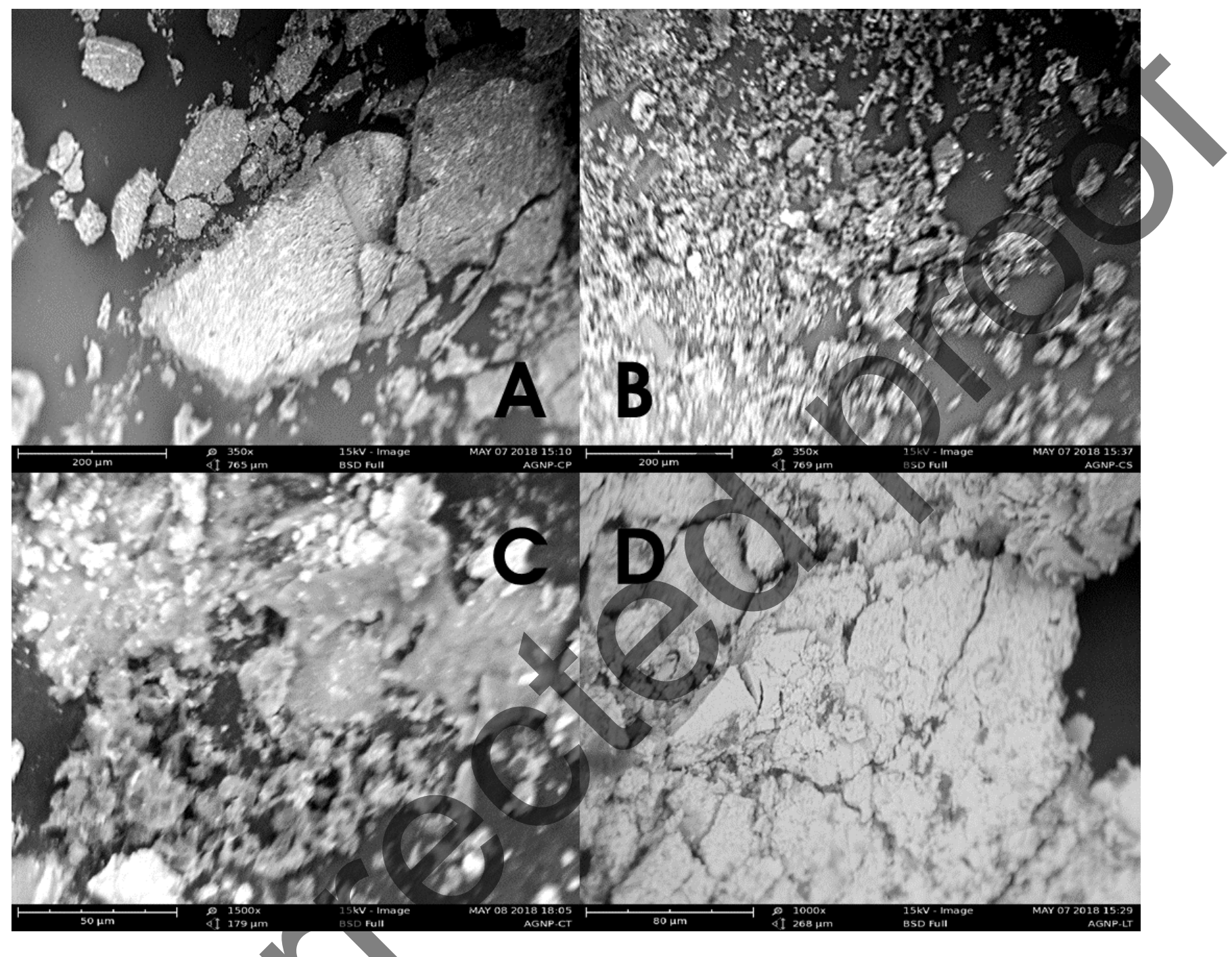

Figure 1: Scanning electron microscope picture $\mathrm{A}=C C-A g N P s ; \mathrm{B}=C S-A g N P s ; \mathrm{C}=\mathrm{CP}-A g N P s ; \mathrm{D}=$ LT-AgNPS 


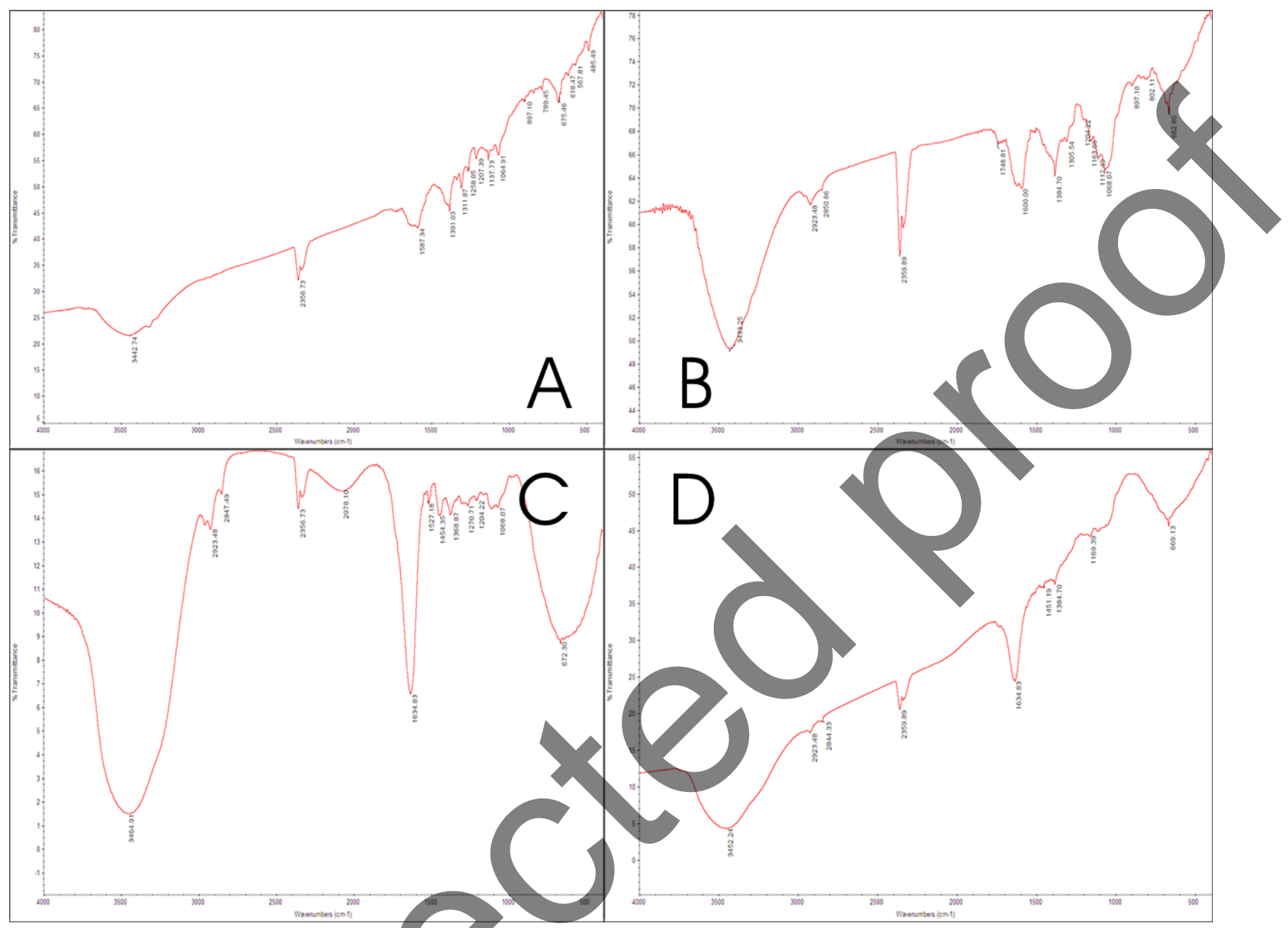

Figure 2: FTIR spectrum of $A=C C-A g N P s ; B=C S-A g N P s ; C=C P-A g N P s ; D=L T-A g N P s$ 


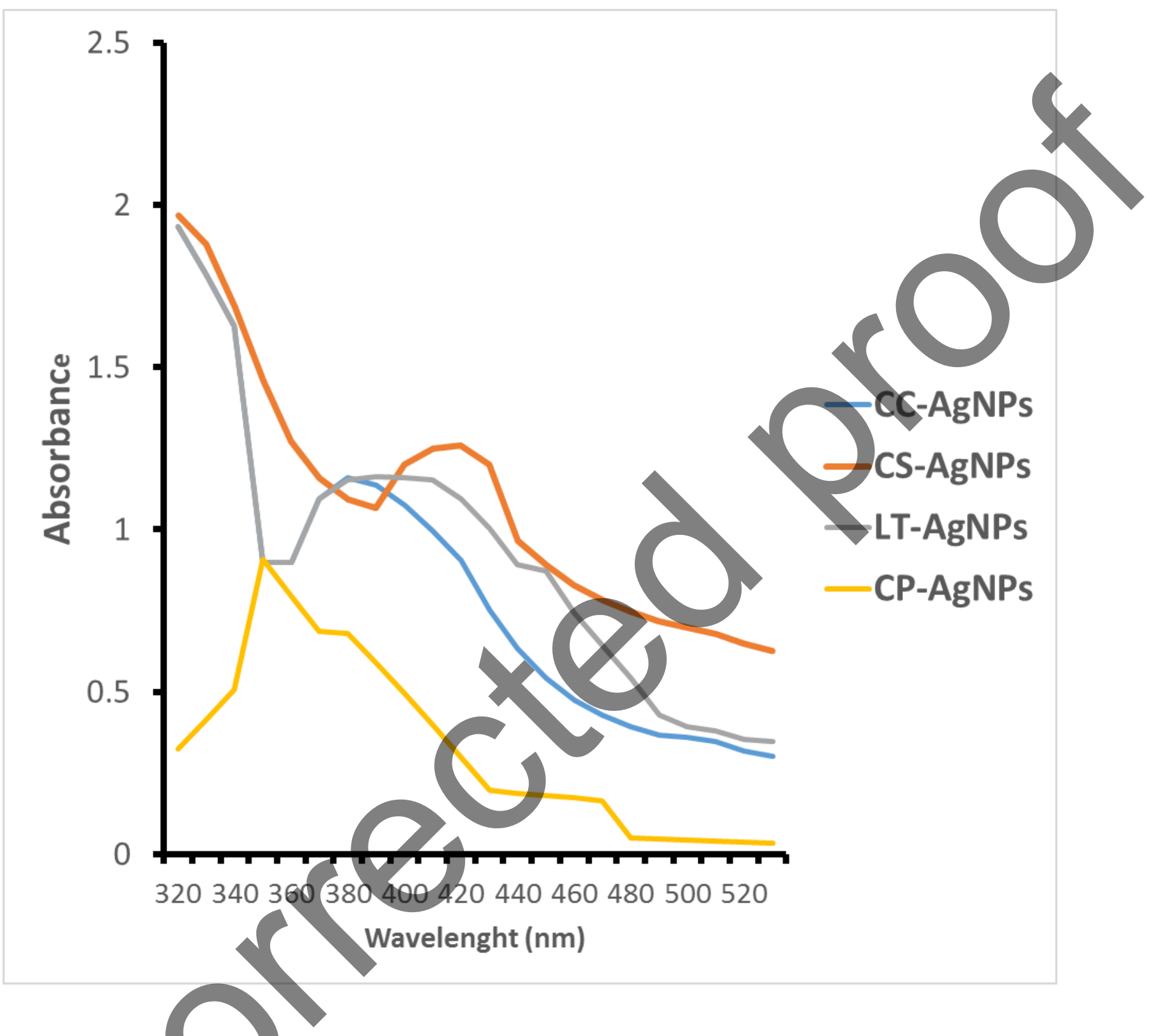

Figure 3: UV-visible spectra of the Synthesized AgNPs 


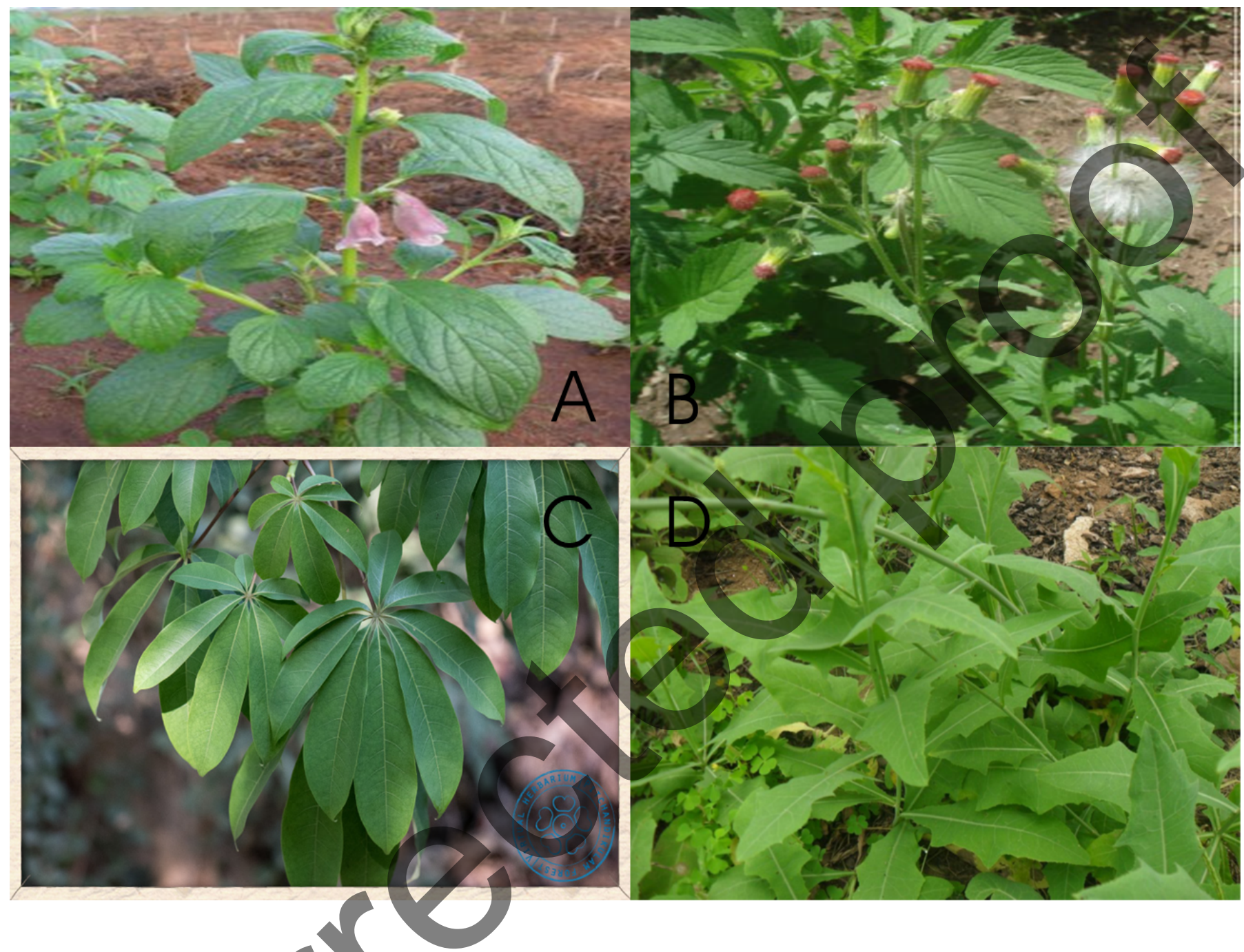

Figure 4: The leaves of $A=C$. crepidioides; $B=C$. sesamoides; $C=C$. pendranta; $D=L$. taraxacifolia

\section{Characterization}

UV-Visible spectroscopy study

Visual inspection showed that colour changes were observed. The colour changes that were witnessed indicate the formation of $C$. crepidioides, C. sesamoides, C. pendranta and $L$. taraxacifolia AgNPs as shown in Table 3. Many studies have shown that AgNPs displayed these colour changes in aqueous solution due to the excitation of surface plasmon resonance (SPR) of AgNPs, this was the first confirmation test that silver nanoparticles have been formed (Kotakadi et al., 2014; Kuppusamy et al., 2014; Sharma et al., 2013; Stephen and Seethalakshmi, 2013; 
Zhang et al., 2016). The AgNPs formed were examined further by the use of UV-Vis spectroscopy which is an imperative and popular tool used for characterization.

It was discovered that the aqueous extract of $C$. sesamoides and $C$. pentandra were able to reduce silver nitrate to silver nanoparticles at $450 \mathrm{~nm}$ being the surface plasmon absorbance peak. among others. Looking at Fig. 3, the curve in each spectrum of synthesized silver nanoparticles that have been absorbed in the wavelength range 380-440 $\mathrm{nm}$ of silver nanoparticle of $C$. sesamoides and $C$. pentandra. The absorption spectra showed a surface plasmon resonance and peaks which were observed at $380 \mathrm{~nm}$ in case of L.taraxacifolia (Fig. 3) whereas the bands for C. crepidioides were observed at $410 \mathrm{~nm}$ as shown in (Fig. 3). This peak falls within the range of specification for nanoparticles as reported by some authors (Sigamoney et al., 2016; Fafal et al., 2017)

\section{FT-IR spectroscopy study}

FTIR spectroscopy measurements was employed to recognize and identify the biological reducing functional group which will give a hint about the likely group of organic compounds present in these wild and non-cultivated vegetables responsible for the reduction of the $\mathrm{Ag}^{+}$ ions to elemental $\mathrm{Ag}^{0}$ and the ensuing capping resulting into efficient stabilization of the $\mathrm{AgNPs}$ formed (Kumar et al., 2014). The FTIR spectra of the synthesized AgNPs of the four vegetables i.e. CC-AgNPs; $B=C S-A g N P s ; C=C P-A g N P s ; D=L T-A g N P s$ are shown in Fig. 2. The Infrared spectrum of CP-AgNPs showed the present of $\mathrm{O}-\mathrm{H}$ functional group with a broadband at $3464.94 \mathrm{~cm}^{-1}$, the IR spectrum of $\mathrm{CP}-\mathrm{AgNPs}$ further revealed $\mathrm{C}=\mathrm{C}$ structure with medium intensity at wavenumber of $1634.33 \mathrm{~cm}^{-1}$ which is $\mathrm{sp}^{2}$ carbon. The IR spectrum of CS-AgNPs shows a very broad band at $3433.48 \mathrm{~cm}^{-1}$ which was assigned to $-\mathrm{OH}$ stretch. It shows a very sharp absorption band at $1748.81 \mathrm{~cm}^{-1}$ which was assigned to $\mathrm{C}=\mathrm{O}$ stretch, there is present of $\mathrm{C}=\mathrm{C}$ functional group at wavenumber of $1600 \mathrm{~cm}^{-1}$. Clear and broad absorbance bands were observed at $3452.24(-\mathrm{OH}), 2923.48-2844.33$ (C-H, stretching), 1634.83 (C=C, stretching),

1451.19-1384.70 (C-H, bending), 1169.39 (C-O) for the LT-AgNPs synthesized (Fig. 2). The intense and broad bands observed at around $3452 \mathrm{~cm}^{-1}$ for all the AgNPs was due to the O-H stretching, which gives an indication for the presence of polyphenols. A medium band observed at around $1634 \mathrm{~cm}^{-1}$ in both the synthesized nanoparticles was attributed to the $-\mathrm{C}=\mathrm{C}-$ 
stretching. The peaks at $1451 \mathrm{~cm}^{-1}$ correspond to $\mathrm{C}-\mathrm{H}$ stretching of the aromatic compounds (Fig. 2). The IR spectrum of CC-AgNPs showed an intense and broad band at $3442.74(-\mathrm{OH}$, stretching), 1587.34 ( $\mathrm{C}=\mathrm{C}$, stretching), 1391.03-1311.87 ( $\mathrm{N}=\mathrm{O}$, stretching), 1258.05-1064.91 (C$\mathrm{O}$, stretching). This give a hint about the presence of alkaloids, flavonoids and others in this plant extract. The peaks at $1587 \mathrm{~cm}^{-1}$ correspond to $\mathrm{C}-\mathrm{H}$ stretching of the aromatic compounds. As shown in Figure 2, most of these spectra proved distinctive functional groups of compounds i.e. Alkaloids, coumarins, flavonoids and phenolic acids which may all have had an active role in the reduction and capping of the synthesized AgNPs.

\section{Scanning Electron Microscope}

Scanning electron microscope identifies the surface characteristics, morphology and the distribution of the CC-AgNPs, CS-AgNPs, CP-AgNPs and LT-AgNPs depicted on the SEM micrograph (Fig 1)., to determine the silver concentration of the nanoparticles. AgNPs generally show a typical absorption characteristic peak at approximately $3 \mathrm{keV}$ due to the surface plasma resonance phenomenon (Prasad et al., 2012). The cracked lines in the SEM micrographs (Figs 1 A-D) would enhance a lamina flow indicating the potential of the AgNPs for toxicant removal (Dada et al., 2017; Dada et al., 2015). The nanoparticles synthesized by these non-cultivated vegetables were highly agglomerated except for CC-AgNPs which displayed a scattered morphology (Fig 1). MubarakAli et al. (2011) ascribes this cluster to a dehydration-induced combination of Ag nanoparticle. Though, CS-AgNPs, CP-AgNPs and LT-AgNPs showed a trend in term of differences in the dimension and magnitude of the synthesized nanoparticles. The study can be credited to the fact that the bigger and bulkier nanoparticles are possible to hold more Ag.

\section{Biological Activities}

Antioxidant Activity

The methanolic extracts of the four non-cultivated vegetables with their corresponding synthesized nanoparticles were evaluated and compared employing two different assays for their antioxidant activity as shown in Table 4. The AgNPs and the methanol extract for each of these plants were evaluated for in-vitro activity employing DPPH and ABTS assays. The results 
are expressed in terms of $\mathrm{IC}_{50}$ (the concentration that caused a $50 \%$ inhibition) and presented in Table 4. These were carried out with in vitro method at various concentrations $(100,200$, $300 \ldots . .500 \mu \mathrm{g} / \mathrm{mL}$ ) of the extracts and AgNPs formed. The synthesized AgNPs of the noncultivated vegetables and the extracts tends to display a significant antioxidant activity at the dose $100 \mu \mathrm{g} / \mathrm{mL}$ concentration, this was noticed with the positive control too. The higher the concentration the less the antioxidant effect that was noticed though there was a climax at 400 $\mu \mathrm{g} / \mathrm{mL}$ as shown in Table 4. From Table 4, it is observed that there is an obvious trend, the synthesized AgNPs displayed a better activity when compared to the extracts of these plants i.e. AgNPs from C. crepiodioides, C. sesamoides, L. taraxacifolia and C. pentandara displayed a better in vitro antioxidant activity $\left(\mathrm{IC}_{50}: 11.4,12.4,11.3,5.5 \mu \mathrm{g} / \mathrm{mL}\right)$ with $A B T S$ assay and $\left({ }^{2} C_{50}\right.$ : $15.4,9.4,13.3$ and $6.4 \mu \mathrm{g} / \mathrm{mL}$ ) using DPPH assay but the methanol extracts of these plants displayed a lower value to the former. CP-AgNPs, CC-AgNPs and LT-AgNPs exhibited the most significant antioxidant effect against ABTS (IC $50: 5.5,11.3$ and $11.4 \mu \mathrm{g} / \mathrm{mL})$ while CP-AgNPs and CS-AgNPs displayed the most significant antioxidant activity against DPPH (IC $50: 6.4$ and 9.4 $\mu \mathrm{g} / \mathrm{mL}$ ) when compared to the positive control used ascorbic acid ( $\left(C_{50}: 4.7 \mu \mathrm{g} / \mathrm{mL}\right)$. Most of the AgNPs formed showed the most significant result at $100 \mu \mathrm{g} / \mathrm{mL}$ though the positive control gave the best result at this dose too (Table 4). Higher plants always contain constituents and substances with antioxidant effect. Flavonoids are one of these naturally occurring substances that are widely renowned to exert scavenging ability against superoxide, free and hydroxyl radicals (Chang et al., 2002). In this study, we assess the antioxidant of the AgNPs of the noncultivated vegetables and their methanolic extracts because of the multifaceted and complex nature of compounds in plants, the antioxidant nature of these AgNPs and their extracts cannot be studied by only a single method. As a result of this, the generally accepted assays i.e. DPPH and ABTS methods were used in this study. Though, CP-AgNPs display a significant antioxidant activity in both assays employed but CS-AgNPs only showed a good antioxidant activity in DPPH assay only. The DPPH and ABTS antioxidant assays proves that these neglected vegetables with their synthesized AgNPs portend antioxidant activity. Bello et al., 2018c reported that antioxidant of the leaves of L. taraxacifolia and C. pentandara (Methanol extracts). These plant 
species displayed significant antioxidant activity when ABTS assay was employed as compared with ascorbic acid.

\section{Anti-inflammatory Activity}

The methanolic extracts of the four non-cultivated vegetables with their corresponding synthesized nanoparticles were evaluated and compared using cell-based assays for their antiinflammatory activity as shown in Table 5. The AgNPs and the methanol extract for each of these plants were evaluated for in vitro activity employing the Human Red Blood Cell Membrane Stabilization method and lipoxidase Assay. The results are expressed in terms of $\mathrm{IC}_{50}$ (the concentration that caused a $50 \%$ inhibition) and presented in Table 5. These were carried out with in vitro method at various concentrations $(100,200,300 \ldots .500 \mu \mathrm{g} / \mathrm{mL})$ of the extract. The extract tends to display a significant anti-inflammatory activity at $100 \mu \mathrm{g} / \mathrm{ml}$ concentration, this was noticed with the positive control too. The higher the concentration the less the antiinflammatory effect that was noticed though there was a climax at $400 \mu \mathrm{g} / \mathrm{mL}$ as shown in Table 5. From Table 5, it is observed that there is an obvious trend, the synthesized AgNPs displayed a better activity when compared to the extracts of these plants i.e. AgNPs from $C$. crepiodioides, C. sesamoides, C. pentandara and L. taraxacifolia displayed a better in vitro antiinflammatory activity ( $\left(\mathrm{C}_{50}: 32.2,38.5,56.4,34.7 \mu \mathrm{g} / \mathrm{mL}\right.$ ) against Human Red Blood Cell Membrane (HRBC) and (IC50: 57.6, 32.8, 55.4, $48.5 \mu \mathrm{g} / \mathrm{mL}$ ) against lipoxygenases but the methanol extracts of these plants displayed a lower value to the former. AgNPs from $C$. crepiodioides, C. sesamoides, L. taraxacifolia and C. pentandara exhibit $\mathrm{IC}_{50}(32.2,38.5,56.4$, $34.7 \mu \mathrm{g} / \mathrm{mL}$ ) against Human Red Blood Cell Membrane (HRBC) and showed inhibitory activity (IC 50 : 57.6, 32.8, 55.4, 48.5 $\mathrm{\mu g} / \mathrm{mL}$ ) against lipoxygenases. CC-AgNPs and CP-AgNPs exhibited the most significant inhibitory activity against $\mathrm{HRBC}\left(\mathrm{IC}_{50}: 32.2\right.$ and $\left.34.7 \mu \mathrm{g} / \mathrm{mL}\right)$ while CS-AgNPs and LT-AgNPs displayed the most significant inhibitory activity against lipoxygenases (IC $50: 32.8$ and $48.5 \mu \mathrm{g} / \mathrm{mL}$ ) when compared to the positive control used indomethacin (IC $50: 28.1 \mu \mathrm{g} / \mathrm{mL}$ ). Most of the AgNPs formed showed the most significant result at $100 \mu \mathrm{g} / \mathrm{mL}$ though the positive control gave the best result at this dose too. CS-AgNPs and LT-AgNPs displayed good activity against LOX assay employed, they could serve well as LOX inhibitors. It is so surprising to note that they display a moderate activity in the other assay used. Some authors have reported the 
anti-inflammatory activity of $C$. pendantara through LOX assay. It was reported that the methanol extract of its leaves displayed an inhibitory activity against LOX with an IC $\mathrm{C}_{50}: 102.4$ $\mu \mathrm{g} / \mathrm{mL}$ when compared with that of the positive control $90.4 \mu \mathrm{g} / \mathrm{mL}$ (Indomethacin) (Bello et al., 2018b), This neglected vegetable (C. pendantara) extracts exhibited inhibitory activity against LOX with an $\mathrm{IC}_{50}: 53.6 \mu \mathrm{g} / \mathrm{mL}$. Lipoxygenases are present in airway and stomach epithelium, leukocytes, gut cells, they aid in the introduction of an oxygen molecule to the 5-position of arachidonic acid to give the intermediate (5S)-hydroxy-(6E,8Z,11Z,14Z)-eicosatetraenoic acid or 5- HETE. This is an important aspect of anti-inflammatory activity at lipoxygenase assay hence inhibiting the biological genesis of leukotriene and 5-HETE. Hence, the search for specific inhibitors of lipoxygenase activity from medicinal plants is on-going and so imperative. Lipoxygenase inhibitors i.e. C. sesamoides, L. taraxacifolia, CS-AgNPs and LT-AgNPs could possess some great advantage for the treatment of allergic rhinitis, arthritis, asthma, atherosclerosis, cancer, osteoporosis, and psoriasis (Fukuishi et al., 2001 and Dana et al., 2002).

\section{Future Direction and Conclusions}

Future studies will be carried out using various chromatographic techniques, spectroscopic techniques and Mass spectrometry (MS) to isolated and elucidate the bioactive compounds in the active fractions of the wild and non-cultivated vegetables. Determination of the specific receptors these active plants' extracts and their corresponding synthesized AgNPs might be acting on to elicit anti-inflammatory effects. There should be in vivo testing on small mammals to verify the anti-inflammatory of these compounds in living organisms. Because both AgNPs of C. crepiodioides and C. sesamoides significantly inhibited inflammatory response, it would be interesting to assay other plants from these families for anti-inflammatory activity. The phytobiological facilitated production of AgNPs from selected non-cultivated vegetables proves to be eco-friendly and successful. In this current research, it has been shown that the synthesis of AgNPs by a simple, cost effective, non-toxic and reproducible way of green chemistry method allows for better antioxidant and anti-inflammation worth. This study reports for the first time the synthesis, characterization, anti-inflammatory and antioxidant activities of CSAgNPs, CP-AgNPs and LT-AgNPs. The synthesized AgNPs were found to be stable and the FTIR evidence suggested that the phytochemicals might have played an important role in the 
reduction and stabilization of AgNPs. This work showed that the synthesized AgNPs from noncultivated vegetable can find relevance and application in health, drugs, food and environmental science. The evidences herein further confirmed their ethnopharmacological applications.

\section{Conflict of Interest}

No conflict of interest among the authors based.

\section{Funding}

No funding was received for this study.

\section{References}

Abubakar, M.S., Musa, A.M., Ahmeda, A., and Hussaini, I.M., (2007). The perception and practice of traditional medicine in the treatment of cancers and inflammations by the Hausa and Fulani tribes of Northern Nigeria. J. Ethnopharmacol. 111, pp 625-629.

Adebisi, A. A. (1966). Launaea taraxacifolia (Willd.) Amin ex C. Jeffrey. In: PROTA 2: Vegetables/Legumes. Kew Bull. London, 18: 474

Adebisi, A.A. (2000) Population of Neglected Indigenous Leafy Vegetables among the Yoruba tribe of South West Nigeria. CERNARD Development Series 06 CERNARD, Ibadan, Nigeria. pp. 86.

Adeniyi S. A. Ehiagbonare J.E. and S. C. O. Nwangwu, (2012) "Nutritional evaluation of some staple leafy vegetables in Nigeria. The Open Complementary Medicine Journal. Vol. 2, 7-14

Adimonyemma N Ruffina, Chukwuma O Maureen, Akachukwu E Esther, Iroka F Chisom (2016). Phytochemical Analysis and Antibacterial Activity of Launaea taraxacifolia Ethanolic Leave Extract. Sch. Acad. J. Biosci., 4(3A):193-196.

Adinortey M. B., Sarfo J. K., Quayson E. T., Weremfo A., Adinortey C. A., Ekloh W., Ocran J. (2012). Phytochemical screening, proximate and mineral composition of Launaea taraxacifolia leaves. Res.

Aloke C., Nachukwu N., Idenyi J.N., Ugwuja E.I., Nwachi E.U., Edeogu C.O. (2010). Hypoglycaemic and Hypolipidaemic Effects of Feed Formulated with Ceiba pentandra Leaves in Alloxan Induced Diabetic Rats. Australian Journal of Basic \& Applied Sciences.4(9): 4473-4477.

Amujoyegbe O.O., Idu M., Agbedahunsi J. M., Erhabor J.O. (2015). Ethnomedicinal Survey of medicinal plants used in the management of sickle cell disorder in Southern Nigeria. Journal of Ethnopharmacology. doi.org/10.1016/j.jep.2016.03.042. 
Anigo, K. M. B., Dauda, M. D., Sallau, A. B., and Chindo, I. E., (2012). "Chemical composition of Kapok (Ceiba pentandra) seed and physicochemical properties of its oil", Nigerian Journal of Basic and Applied Science. 21(2),105-108.

Aniya Y, Koyama T, Miyagi C, Miyahira M, Inomata C, Kinoshita S, Ichiba T. 2005. Free radical scavenging and hepatoprotective actions of the medicinal herb, Crassocephalum crepidioides from the Okinawa Islands. Biol Pharm Bull; 28: 19-23.

Anosike C., Ojeli P., and Abugu S. (2014). Antiulcerogenic effects and anti-oxidative properties of Ceiba pentandra leaves on alloxan-induced diabetic rats. European Journal of Medicinal Plants 4(4):458-472.

Antia, B.S., E.J. Akpan, P.A. Okon and I.U. Umoren, (2006). Nutritive and Anti. Nutritive Evaluation of sweet potatoes (Ipomoea batatas) Leaves. Pak. J. Nutr., 5:166-168.

Arawande, J.O.; Amoo, I.A.; Lajide, L. (2013). Chemical and Phytochemical Composition of Wild Lettuce Launaea taraxacifolia. Journal of Applied Phytotechnology in Environmental Sanitation, 2: 25-30.

Arawande, J.O.; Komolafe, E.A.; Imokhuede, B. (2013). Nutritional and phytochemical compositions of fireweed (Crassocephalum crepidioides). Journal of Agricultural Technology, 9(2): 439-449.

Asada Y, Shiraishi M, Takeuchi T, Osawa Y, Furuya T. (1985). Pyrrolizidine alkaloids from Crassocephalum crepidioides. Planta Medica 51: 539-540.

Atolani, O., Omere, J., Otuechere, C. A., Adewuyi, A. (2012). Antioxidant and cytotoxicity effects of seed oils from edible fruits. Journal of Acute Disease, 1, pp 130-134.

Bamishaiye E. I., Olayemi F. F., Awagu E. F., and Bamishaiye M. O (2011) "Proximate and phytochemical composition of Moringa oleifera leaves at three stages of maturation", Advance Journal of Food Science and Technology. Vol. 3(4): 233-237. Southern Nigeria" International Journal of Agricultural and Food Science. Vol. 2(2), 37-43.

Bedigian, D. and Adetula, A.O., (2004). Ceratotheca sesamoides Endl. Prota 2: Vegetables/ Legumes. PROTA, Wageningen, The Netherlands. pp 34-36.

Bedigian, D., (2003). Evolution of sesame revisited: Domestication, diversity and prospects. Genet. Resour. Crop. Evol. 50, pp 779-787.

Bello Oluwasesan M., Abiodun B. Ogbesejana and Uduma A. Uduma (2018b). Launaea taraxacifolia; a Neglected Vegetable from Nigeria, its Anti-inflammatory and Antioxidant Activities. ChemSearch Journal 9(1): 9 - 12.

Bello, O. M., Ibitoye T., \& Adetunji, C. (2018). Assessing antimicrobial agents of Nigeria flora Journal of King Saud University - Science, doi.org/10.1016/j.jksus.2018.04.017.

Bello, O. M., Ogbesejana, A. B. and Tijjani, A. (2018c). Lipoxygenase (Lox) Inhibitory Activity of Leaves of Ceiba Pentandra (L.) Gaertn: A Neglected Vegetable from Nigeria. FUDMA Journal of Sciences, 2(2); 79-82. 
Bello, O.M., Zaki, A.A., Khan, I.S., Fasinu, P.S., Ali, Z., Khan, I.A., Usman, L.A. \& Oguntoye, O.S. (2017). Assessment of selected medicinal plants indigenous to West Africa for antiprotozoal activity. South Africa Journal of Botany https://doi.org/10.1016/jsajb.2017.08.002

Benoit-Vical, F., Soh, P.N., Saléry, M., Harguem, L., Poupat, C., Nongonierma, R., (2008). Evaluation of Senegalese plants used in malaria treatment: focus on Chrozophora senegalensis. J. Ethnopharmacol. 116, pp 43-48.

Bukola C. Adedayo, Ganiyu Oboh, Sunday I. Oyeleye, Isaac I. Ejakpovi, Aline A. Boligon and Margareth L. Athayde, (2015). Blanching alters the phenolic constituents and in vitro antioxidant and anticholinesterases properties of fireweed (Crassocephalum crepidioides). Journal of Taibah University Medical Sciences 10(4), 419-426. doi.org/10.1016/j.jtumed.2015.09.003.

Burkill, H. M. (1985). In: The useful plants of West tropical Africa, Vol3, Royal Botanic Gardens, Kew, UK. pp. 133-136.

Burkill, H.M. (1995). The useful plants of west tropical Africa 2ed. Royal Botanical Garden, Kew, London, pp. 160-164.

Chang W. Choi, Sei C. Kim, Soon S. Hwang, Bong K. Choi, Hye J. Ahn, Min Y. Lee, Sang H. Park, Soo K. Kim (2002). Antioxidant activity and free radical scavenging capacity between Korean medicinal plants and flavonoids by assay-guided comparison. Plant Science 163; 1161-1168.

Dada, A. O., Inyinbor, A. A., Idu, I. E., Bello, O.M., Oluyori, A. P., Adelani-Akande, T. A., Okunola, A. A., Dada, O. (2018). Effect of operational parameters, characterization and antibacterial studies of green synthesis of Silver Nanoparticles, using Tithonia diversifolia. PeerJ 6:e5865; DOI 10.7717 /peerj.5865

Dada, A. O., Adekola, F. A. and Odebunmi, E. O. (2017). Liquid Phase Scavenging of Cd (II) and $\mathrm{Cu}$ (II) ions onto novel nanoscale zerovalent manganese (nZVMn): Equilibrium, Kinetic and Thermodynamic Studies. Environmental Nanotechnology, Monitoring \& Management, 8, 6372://dx.doi.org/10.1016/j.enmm.2017.05.001

Dada, A.O., Adekola, F.A. and Odebunmi, E.O. (2016). Kinetics and equilibrium models for Sorption of $\mathrm{Cu}$ (II) onto a Novel Manganese Nano-adsorbent. Journal of Dispersion Science and Technology, 37(1), 119-133. DOI: 10.1080/01932691.2015.103461

Dairo Joshua Olugbenga, Ukpanukpong, Richard Undigweundeye, Uyabeme Rachael Ngozi (2015). Phytochemical Screening, Proximate Analysis and Acute Toxicity Study of Launaea taraxacifolia Ethanolic Extract on Albino Rats. The International J. of Science \& Techn. Vol 3 Issue 6; 199-202.

Dhellot, J.R., E. Matouba, M.G. Maloumbi, J.M. Nzikou, D.G. SafouNgoma, M. Linder, S. Desobry and M. Parmentier, (2006a). Extraction, chemical composition and nutritional characterization of vegetable oils: case of Amaranthus hybridus (var 1 and 2) Longo Brazzaville. Afr. J. Biotech., 5: 1095- 1101. 
Dhellot, J.R., E. Matouba, M.G. Maloumbi, J.M. Nzikou, M.G. Dzondo, M. Linder, M. Parmentier and S. Desobry, (2006b). Extraction and nutritional properties of Solanum nigrum L. seed oil. Afr. J. Biotech., 5: 987-991.

Diarra, N., Klooster, C., Togola, A., Diallo, D., Willcox, M., Jong, J., (2015). Ethnobotanical study of plants used against malaria in Sélingué subdistrict, Mali. J. Ethnopharmacol. 166, pp 352360.

Edmonds, J.M. and J.A. Chweya, (1997). Promoting the conservation and use of under-utilized and neglected crops: Black nightshades (Solanum nigrum L.) and related species. International Plant Genetic Resources Institute, Rome, Italy, pp: 1-90.

Enechi, D. C., Ugwu, K. K., Ugwu, O. P. C., and Omeh, Y. S. (2013). "Evaluation of the antinutrient levels of Ceiba pentandra leaves", International Journal of Research and Review in Pharmacy and Applied Science. 3(3), 394-400.

Fafal T., Taştan P., Tüzüna B.S., M. Ozyazici, Bijen Kivcak. (2017). Synthesis, characterization and studies on antioxidant activity of silver nanoparticles using Asphodelus aestivus Brot. aerial part extract. South African Journal of Botany 112:346-353.

Fasola, T., Ogunsola, O., (2014). The proximate and phytochemical composition of Sesamum indicum Linn and Ceratotheca sesamoides Endl at different stages of growth. J. Biol. Agric. Healthc. 4, pp 84-88.

Fleuret, A., (1979). The role of wild foidage plants in the Characterization and diet. A case study from Lushuto, Tanzania. Ecol. Food Nutr., 8: 87-93.

Fukuishi N, Takada T, Fukuyama Y, Akagi M. (2001). Antiallergic effect of ardisiaquinone A, a potent 5-lipoxygenase inhibitor. Phytomedicine, 8:460-464.

Dana A, Ilse Z, Dingermann T, Müller WE, Steinhilber D, Werz O. (2002). Hyperforin is a dual inhibitor of cyclooxygenase-1 and 5-lipoxygenase. Biochem Pharmacol 64: 1767-1775.

Gbadamosi. I. T. and Okolosi O. (2013). Botanical galactogogues: nutritional values and therapeutic potentials. Journal of Applied Biosciences 61: 4460-4469.

Grubben, G.J.H., Denton, O.A., (2004). Ceratotheca sesamoides Endl. In: Bedigian, D., Adetula, O.A. (Eds.), Plant Resources of Tropical Africa, vol. 2. Vegetables PROTA Foundation. Backhuys Publishers, Wageningen, Netherlands. pp 56.

Harborne, J.B., (1973). Phytochemical methods. A guide to Collection and Preparation of Plant Materials modern methods of plants analysis. Chapman and hall, New York., pp: 7-43.

Jayandran, M.; Muhamed, H.M.; Balasubramanian, V. (2015). Green synthesis and characterization of Manganese nanoparticles using natural plant extracts and its evaluation of antímicrobial activity. Journal of Applied Pharmaceutical Science. 5(12): 105-110.

Jimoh F. O., Adedapo A. A., Aliero A. A., Koduru S. and Afolayan A. J., (2010). Evaluation of the polyphenolic, nutritive and biological activities of the acetone, methanol and water extracts of Amaranthus asper", The Open Complementary Medicine Journal. Vol. 2, 7-14. 
Konan, Y., Witabouna, K.M., Bassirou, B., Kagoyire, K., (2014). Antioxidant activity and total phenolic content of nine plants from Côte d'Ivoire (West Africa). J. Appl. Pharm. Sci. 4, pp 036041.

Kotakadi, V.S., Gaddam, S.A., Subba Rao, Y., Prasad, T.N.V.K.V., Varada Reddy, A., Sai Gopal, D.V.R., (2014). Biofabrication of silver nanoparticles using Andrographis paniculata. European Journal of Medicinal Chemistry 73. https://doi.org/10.1016/j.ejmech.2013.12.004.

Koukoui O., M. Senou, P. Agbangnan, S. Seton, F. Koumayo, S. Azonbakin, M. Adjagba, A. Laleye and A. Sezan (2017) Effective in vivo Cholesterol and Triglycerides Lowering Activities of Hydroethanolic Extract of Launaea taraxacifolia Leaves. IJPSR; Vol. 8(5): 2040-2047.

Koukoui, O., Agbangnan, P., Boucherie, S., Yovo, M., Nusse, O., Combettes, L., Sohounhloué, D. (2015). Phytochemical Study and Evaluation of Cytotoxicity, Antioxidant and Hypolipidemic Properties of Launaea taraxacifolia Leaves Extracts on Cell Lines HepG2 and PLB98. American Journal of Plant Sciences 6: 1768-1779.

Kumar, D.A., Palanichamy, V., Roopan, S.M., (2014). Green synthesis of silver nanoparticles using Alternanthera dentata leaf extract at room temperature and their antimicrobial activity. Spectrochimica Acta - Part A: Molecular and Biomolecular Spectroscopy 127, 168-171.

Kuppusamy, P., Yusoff, M.M., Maniam, G.P., Govindan, N., (2014). Biosynthesis of metallic nanoparticles using plant derivatives and their new avenues in pharmacological applications an updated report. Saudi Pharmaceutical Journal https://doi.org/10.1016/j.jsps.2014.11.013.

López-Mata, M. A., Ruiz-Cruz, S., Silva-Beltrán, N. P., Ornelas-Paz, J. d. J., Ocaño-Higuera, V. M., Rodríguez-Félix, F., Shirai, K. (2015). Physicochemical and antioxidant properties of chitosan films incorporated with cinnamon oil. International Journal of Polymer Science, 10 (2): 23-36.

Lydia, E.K. (2012). Safety Assessment of the Ethanolic Leaf Extract of Launaea Taraxacifolia (Willd) of the Family Asteraceae in Rodents. M. Ph. Thesis, Kwame Nkrumah University of Science and Technology, Kumasi, Ghana. pp. 110.

Mohammed, R.S.; Zuhur, J.; Qandeel, A.; Mujeeb, K.; Mufsir, K.; Mohamed, E.A.; Hamad, Z.A.; Abdulrahman, A-W.; Rafiq, H.S.; Merajuddin, K.; Syed F.A. (2017); Green Synthesis and Characterization of Palladium Nanoparticles Using Origanum vulgare L. Extract and Their Catalytic Activity. Molecules, 22: 165.

Molander, M., Nielsen, L., Søgaard, S., Staerk, D., Rønsted, N., Diallo, D., Chifundera, K.Z., Van Staden, J., Jäger, A.K., (2014). Hyaluronidase, phospholipase A2 and protease inhibitory activity of plants used in traditional treatment of snakebite induced tissue necrosis in Mali, DR Congo and South Africa. J. Ethnopharmacol. 157, pp 171-180.

MubarakAli, D., Thajuddin, N., Jeganathan, K., Gunasekaran, M., (2011). Plant extract mediated synthesis of silver and gold nanoparticles and its antibacterial activity against clinically isolated pathogens. Colloids Surf. B: Biointerfaces 85, 360-365. 
Musa AA, Adekomi DA, Tijani AA, Muhammed OA., (2011). Some of the effect of Crassocephalum crepidioides on the frontal cortex, kidney, liver and testis of adult male Sprague Dawley rats: microanatomical study. Eur J Exp Biol 2011; 1: 228-235.

Nadembega, P., Boussim, J.I., Nikiema, J.B., Poli, F., Antognoni, F., (2011). Medicinal plants in Baskoure, Kourittenga Province, Burkina Faso: an ethnobotanical study. J. Ethnopharmacol. 133, pp 378-395.

Obi, R.K., Iroagba, I.I., Ojiako, O.A., (2006). Virucidal potential of some edible Nigerian vegetables. Afr. J. Biotechnol. 5, pp 1785-1788.

Oguntoye S. Olubunmi, Bello Oluwasesan M., Emmanuel Opeyemi, Dada Adewumi Oluwasogo, Abdulmeen Hamid (2018). Acetylcholinesterase inhibition and antioxidant evaluation of polyphenolic fractions and oil from four melon seeds used as condiments in Nigeria. Carpathian Journal of Food Science and Technology, 10 (1);82-94.

Olatunde Owoeye and Ganiyu O. Arinola (2017). A Vegetable, Launaea taraxacifolia, Mitigated Mercuric Chloride Alteration of the Microanatomy of Rat Brain. Journal of Dietary Supplements.,4 (6), 613-625.

Olugbenga D. J., Undigweundeye U. R., Ngozi U. R. (2015). Rhytochemical screening, proximate analysis and acute toxicity study of Launea taraxacifolia ethanolic extract on albino rats. Int J Sci Tech; 3: $199-202$.

Omoti, O. and P.A. Okyi, (1987). Characterization and composition of the pulp oil and cake of the African Dacryodes edulis. J. Sci. food Agric., 38: 67-70.

Onyenuga, V.A. and B.L. Fetuga, (1995). First National seminar on fruits and vegetables. In: proc and Recom. And papers by NITHORT, Ibadan, Nigeria.

Owoeye O. and Onwuka S. K., (2016). Lead toxicity. Effect of Launaea taraxacifolia on the histological and oxidative alterations in rat region II cornu ammonis and cerebellum. Anat J Afr; 5: $783-794$.

Owoeye O., Gbadamosi I. T., Alia A. E., Okolosi O. (2012). In - vitro antimicrobial activities and nutritional assessment of roots of ten Nigerian vegetables. NY Scie. J; 5: $234-240$.

Oyedapo 0. O, Akinpelu B. A., Orefuwa S. O. (2004). Anti-inflammatory effects of Theobroma cacao, L. root extract. J. of Tropical Med. Plants (Malaysia) 5(2):161-166.

Oyedapo O. O., Sab F. C., Olagunju J. A. (1999). Bioactivity of fresh leaves of Lantana camara. Biomed. Lett. 59: 175- 183.

Oyedapo OO, Akindele VR, Okunfolami KO (1997). Effects of the extracts of Olax subcorpiodes and Aspilia Africana on bovine red blood cells. Phytotherapy Res. 11:305-306.

Paul Ssegawa and John Massan Kasenene (2007). Medicinal plant diversity and uses in the Sango bay area, Southern Uganda. Journal of Ethnopharmacology 113: 521-540. 
Prasad, T.N.V.K.V., Kambala, V.S.R., Naidu, R., (2012). Phyconanotechnology: synthesis of silver nanoparticles using brown marine algae Cystophora moniliformis and their characterization. Journal of Applied Phycology http://dx.doi.org/10.1007/s10811-012-9851-z.

Ramar, M. (2015) Synthesis of Silver Nanoparticles using Natural products from Acalypha indica and Curcuma longa. International Journal of Pharmaceutical Research and Bio-Science, 4(1): 151-164.

Robert, O.B. (1955); The Typification of Crassocephalum moench and Gynura cass. Kew Bulletin, London,10 (3): 455-465.

Sathiraju, A.; Yathapu, S.; Bojja, S.; Ganghishetti, B.; Singh, A.K. (2014). Characterization of Green Synthesized Copper Nanoparticles Stabilized by Ocimum Leaf Extract. Mater. Res. Soc. Symp. Proc., India, 1704: 6. Doi: 10.1557/opl.2014.806.

Sharma, S., Kumar, S., Bulchandani, B.D., Taneja, S., Banyal, S., (2013). Green synthesis of silver nanoparticles and their antimicrobial activity against Gram-positive and Gram-negative bacteria. International Journal of Biotechnology and Bioengineering 4, 711-714.

Shinde, U.A.; Kulkarni K.R.; Phadke A.S.; Nair A.M.; Dikshit V.J.; Saraf M.N. (1999). Mastcell stabilizing and lipoxygenase inhibitory activity of Cedrus deodara (Roxb.) Loud wood Oil. Indian J. Exp. Biol, 37(3): 258-261.

Sigamoney M., Shaik, S., Govender, P., Krishna, S. B.N., Sershen. (2016). African leafy vegetables as bio-factories for silver nanoparticles: A case study on Amaranthus dubius C Mart. Ex Thell. South African Journal of Botany 103:230-240.

Soelberg J., Asase A, Akwetey, G., Jäger A.K., (2015). Historical versus contemporary medicinal plant uses in Ghana. Journal of Ethnopharmacology, 160: 109-132.

Sofowora, E. A. (1993). Medicinal Plants and Traditional Medicine in Africa. 2nd ed. Spectrum Books limited Ibadan, Nigeria, 9 (25): 289.

Steinhilber, D. (1999). 5-Lipoxygenase: a target for anti-inflammatory drugs revisited. Curr. Med. Chem., 6: 69-83.

Stephen, A., Seethalakshmi, S., (2013). Phytochemical synthesis and preliminary characterization of silver nanoparticles using Hesperidin. Journal of Nanoscience 2013, 3-7.

Tomimori K, Nakama S, Kimura R, Tamaki K, Ishikawa C, Mori N., (2012). Antitumor activity and macrophage nitric oxide producing action of medicinal herb, Crassocephalum crepidioides. BMC Complement Altern Med.12: 78.

Toyin, M.Y., Khadijat, O.F., Saoban, S.S., Olakunle, A.T., Abraham, B.F., Luqman, Q.A., (2012). Antidiarrhoeal activity of aqueous leaf extract of Ceratotheca sesamoides in rats. Bangl. J. Pharmacol. 7, pp 14-20.

Trease, G. E. \& Evans, W. C. (1989). A Textbook of Pharmacognosy, 13th ed. Bailliere Tindall Ltd, London, $134 \mathrm{pp}$. 
Van Wyk, B, E., Gericke, N., (2000). People's Plants: A Guide to Useful Plants of Southern Africa. Briza Publications, Pretoria, South Africa. Pp 102.

Vanderjagt, D. J., Freiberger, C., Vu, H.T.N., Mounkaila, G., Glew, R.S., Glew, R.H., (2000). The trypsin inhibitor content of 61 wild edible plant foods of Niger. Plant Foods Hum. Nutr. 55, pp. 335-346.

Wilfried Rozhon, Lukas Kammermeier, Sebastian Schramm, Nayeem Towfique, N. Adebimpe Adedeji, S. Adesola Ajayi and Brigitte Poppenberger, (2018). Quantification of the Pyrrolizidine Alkaloid Jacobine in Crassocephalum crepidioides by Cation Exchange High-Performance Liquid Chromatography. Phytochem. Anal. 29, 48-58. DOI 10.1002/pca.2713.

Zhang, X.F., Liu, Z.G., Shen, W., Gurunathan, S., (2016). Silver nanoparticles: Synthesis, characterization, properties, applications, and therapeutic approaches. International Journal of Molecular Sciences 17:1534. https://doi.org/10.3390/ijms17091534 